\title{
Classifying xylophone bar materials by perceptual, signal processing and wood anatomy analysis
}

\author{
Loïc BRANCHERIAU ${ }^{\mathrm{a} *}$, Henri BAILlÈres $^{\mathrm{a}}$, Pierre DÉTIENNE $^{\mathrm{a}}$ Richard KRONLAND $^{\mathrm{b}}$, Bloen METZGER $^{\mathrm{b}}$ \\ ${ }^{a}$ CIRAD - Forêt, TA10/16, avenue Agropolis, 34398 Montpellier Cedex 5, France \\ ${ }^{b}$ CNRS - LMA, 31 chemin Joseph-Aiguier, 13402 Marseille Cedex 20, France
}

(Received 10 December 2004; accepted 18 May 2005)

\begin{abstract}
Several different areas of expertise are required to analyse the acoustic qualities of wood. The practical experience of musical instrument makers is extremely valuable, especially with respect to selecting the most suitable wood species for different applications. Knowledge on the mechanics and anatomy of wood is also essential to determine the factors underlying the acoustic qualities of woods. In addition, music synthesis research on psychoacoustic issues can highlight perceptual attributes that account for the acoustic qualities of different woods. The present study was focused on 58 tropical wood species used in xylophone-type percussion instruments. Each wood was classified by an xylophone maker and on the basis of an analysis of radiated sound signals and these separate classifications were compared with the aim of determining key signal parameters that have an impact on the acoustic quality of wood. Relationships between perceptual classifications, signal parameters and wood anatomical characteristics were analyzed.
\end{abstract}

wood musical quality / acoustic properties / vibration / wood anatomy

Résumé - Classifications de lames de xylophone par analyse perceptive, traitement du signal et anatomie des bois. Le bois est un matériau essentiel pour la fabrication de nombreux instruments de musique. En évaluer les qualités acoustiques relève de la mise en commun de plusieurs domaines de compétence. D'une part, les luthiers apportent un savoir empirique très précieux qui permet le choix des meilleures essences. D'autre part, les connaissances en mécanique et en anatomie du bois permettent une meilleure compréhension de l'origine de ces qualités. Parallèlement, les recherches en synthèse musicale associées aux problématiques de la psychoacoustique donnent un éclairage sur les attributs perceptifs à l'origine de la qualité acoustique d'une essence. L'étude porte sur une soixantaine d'essences tropicales et se limite aux instruments percussifs de type xylophone. Deux classifications sont réalisées et mises en parallèle, celle du luthier et celle donnée par l'analyse des signaux sonores rayonnés, dans le but d'identifier les paramètres déterminants du signal du point de vue de la qualité acoustique du matériau. Les relations entre une classification perceptive, les paramètres du signal, et des caractéristiques anatomiques sont analysées. Elles permettent de mettre en évidence des critères objectifs et pertinents utilisables pour évaluer la qualité des bois de lutherie.

qualité musicale du bois / propriété acoustique / vibration / anatomie du bois

\section{INTRODUCTION}

Wood is used in making many musical instruments because of the indispensable physical and mechanical properties of this material. The sound quality of wood is perceptually assessed by musical instrument makers and musicians. Analyzing the acoustic qualities of wood is highly complex, and this issue has only been partially dealt with to date. Holz [7] focused on key qualities of wood used for making xylophone bars and proposed a map of around 20 species classified on the basis of their modulus of elasticity, density and damping features. Ono and Norimoto [15] demonstrated that samples of spruce wood (Picea excelsa, P. glehnii, P. sitchensis) - which is considered to be a suitable material for soundboards - all had a high sound velocity and low longitudinal damping coefficient as compared to other softwoods. The cell-wall structure could account for this phenomenon. Internal friction and the longitudinal modulus of elasticity are markedly affected by the microfibril angle in the $\mathrm{S} 2$ tracheid cell layer, but this general trend does not apply to all species. For instance, pernambuco (Guilandina echinata Spreng.), which is traditionally used for making violin bows, has an exceptionally low damping coefficient relative to other hardwoods and softwoods with the same specific modulus [10, 21]. This feature has been explained by the abundance of extractives in this species [11]. Obataya et al. [14] confirmed the importance of extractives for the rigidity and damping qualities of reed materials. Matsunaga et al. [12] reduced the damping coefficient of spruce wood by impregnating samples with extractives of pernambuco (Guilandina echinata Spreng.).

It is essential to know what musical instrument or component is involved when assessing the "acoustic quality" of a

\footnotetext{
*Corresponding author: loic.brancheriau@cirad.fr
} 
wood specimen. Our scientific study was thus designed to gain further insight into the relationship between the physical properties, anatomical characteristics and the perceptual classification of woods to be used in xylophone and marimba type percussion instruments. Hence, a xylophone maker perceptually classified 58 tropical wood species and, based on this classification, key signal parameters pertaining to the acoustic quality of the material were identified. These parameters were then correlated with the physical and anatomical properties of each wood. Finally, we propose a nondestructive method for assessing the quality of woods earmarked for making musical instruments.

\section{MATERIALS AND METHODS}

The study focused on 58 tropical wood species belonging to the tropical wood collection of CIRAD (Tab. I). They were selected in order to cover a wide range of density going from 206 to $1277 \mathrm{~kg} / \mathrm{m}^{3}$. The xylophone maker recommended the following test sample dimensions: $350 \mathrm{~mm}$ long, $45 \mathrm{~mm}$ wide, $20 \mathrm{~mm}$ thick, which was in line with the rough size of the samples and sawing constraints. When possible, the specimens were prismatic, straight grained, knot-free, and without defects. The specimens were cut to minimize the curve of the growth rings, with the ring parallel to the tangential grain of the wood. The longitudinal direction was colinear to the longitudinal axis of the specimens. The specimens were stabilized in a climatic chamber at $65 \%$ ambient humidity and $20{ }^{\circ} \mathrm{C}$ ambient temperature, with a theoretical wood moisture content of $12 \%$ at equilibrium.

\subsection{Classification test of the xylophone maker}

The acoustic space, minus the pitch (mainly linked to frequency), loudness (intensity) and duration, is called the "timbre". Any dimension can be assessed on the basis of perceptual features (as in the present case), described on the basis of semantic attributes, or acoustic features and thus quantified according to signal parameters or "descriptors", or physical features whereby sound source properties are used to describe sound. The differential semantic approach was described by Bismarck [1], a method that involves assessing a set of sounds on digital scales. Grey contributed to the analysis of timbre by using multidimensional statistical analysis methods [6]. In most multidimensional analyses of timbre, the spectral center of gravity and acoustic "assault" (rise time) are the main dimensions of the perceptual space [13]. The third dimension seems to be less stable and varies between studies. Note that these studies were conducted on a broad range of instruments with resonating structures (tubes, balls, strings, etc.) and different excitation modes (rubbing, plucking and percussion).

A xylophone maker conducted a first classification with the wood specimens at hand (multisensory classification) and then, secondly, indirectly on the basis of recorded sounds (acoustic classification). The xylophone maker had access to the wood specimens for 1 week for the multisensory classification. A computer interface was designed for the acoustic classification. All sounds, represented by identical icons, were randomly distributed on the computer screen. The xylophone maker could click on an icon to listen to a sound as many times as he wished, and then he classified the sounds by sorting the icons in order of acoustic quality on the screen. The classification method was described by Bismarck [1], with the wood specimens classified in terms of their "musical suitability" for xylophone bar material.

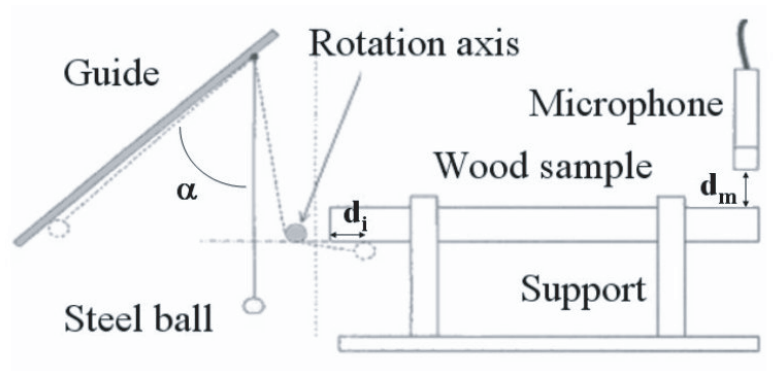

Figure 1. Experimental set up for acoustic radiation measurements $\left(\alpha=30^{\circ}, d_{\mathrm{i}}=1.5 \mathrm{~cm}, d_{\mathrm{m}}=2.5 \mathrm{~cm}\right)$.

\subsection{Dynamic test}

\subsubsection{Test procedure}

The system for measuring the acoustic signal radiated via the wood specimens was designed to obtain an accurate analysis of the mechanical and acoustic properties of the material, while also enabling the xylophone maker to classify the species (Fig. 1). It was thus important to conduct the analyses in conditions resembling those in which a musician would play a xylophone. The prismatic-shaped wood samples were set on two elastic supports with a very low vibration frequency $(<10 \mathrm{~Hz})$. A pendulum, consisting of a nylon cord $(30 \mathrm{~cm}$ long) and a metal ball (14 mm diameter, $12 \mathrm{~g}$ weight), was set in motion to trigger a vibration in the wood specimen by hitting the end with the metal ball. An omnidirectional microphone was placed at the other end to measure the acoustic pressure radiated at impact.

The data acquisition system included a NEUMAN KM183 MT microphone, a DIGIDESIGN 001 converter (48 kHz sampling frequency, 16 bit resolution) and the PROTOOLS software package. The sounds were produced and recorded in an anechoic room $(70 \mathrm{~Hz}$ cutoff frequency). The test table was covered entirely with an absorbent material (melamine).

\subsubsection{Signal processing}

Sound signal "descriptor" parameters were used within the frequency space in the first approach which was designed to accurately analyze the timbre of the tested wood samples. The Spectral Center of Gravity ( $S C G$ ) was thus determined (1), along with the Spectral Range $(S R)(2)$ and the harmonicity factor $(H F)(3)$.

$$
S C G=\frac{\sum_{i=1}^{N} A_{i} f_{i}}{\sum_{i=1}^{N} A_{i}}
$$

where $A_{i}$ is the modulus of the discrete Fourier transform at frequency $f_{i}$.

$$
\begin{gathered}
S R=\sqrt{\frac{\sum_{i=1}^{N} A_{i}\left(f_{i}-S C G\right)^{2}}{\sum_{i=1}^{N} A_{i}}} \\
H F(i)=\frac{\text { resonance frequency of rank } i}{\text { fundamental frequency }}-i .
\end{gathered}
$$


Table I. List of wood species.

\begin{tabular}{|c|c|c|c|}
\hline Database No. & Botanical name & Country & Density $\left(\mathrm{kg} / \mathrm{m}^{3}\right)$ \\
\hline 4271 & Scottellia klaineana Pierre & Côte d'Ivoire & 629 \\
\hline 5329 & Ongokea gore Pierre & Congo & 842 \\
\hline 6704 & Humbertia madagascariensis Lamk. & Madagascar & 1234 \\
\hline 6779 & Ocotea rubra Mez & French Guiana & 623 \\
\hline 6966 & Khaya grandifoliola C.DC. & Côte d'Ivoire & 646 \\
\hline 7021 & Khaya senegalensis A.Juss. & Burkina Faso & 792 \\
\hline 7299 & Coula edulis Baill. & Cameroon & 1048 \\
\hline 11136 & Tarrietia javanica $\mathrm{Bl}$ & Cambodia & 780 \\
\hline 13293 & Entandrophragma cylindricum Sprague & Côte d'Ivoire & 734 \\
\hline 14233 & Afzelia pachyloba Harms & Cameroon & 742 \\
\hline 14440 & Swietenia macrophylla King & Martinique & 571 \\
\hline 14814 & Aucoumea klaineana Pierre & Congo & 399 \\
\hline 15366 & Humbertia madagascariensis Lamk. & Madagascar & 1277 \\
\hline 15377 & Faucherea thouvenotii H.Lec. & Madagascar & 1061 \\
\hline 15717 & Ceiba pentandra Gaertn. & Côte d'Ivoire & 299 \\
\hline 16001 & Letestua durissima H.Lec. & Congo & 1046 \\
\hline 16084 & Monopetalanthus heitzii Pellegr. & Gabon & 466 \\
\hline 16136 & Commiphora sp. & Madagascar & 390 \\
\hline 16211 & Dalbergia sp. & Madagascar & 916 \\
\hline 16624 & Hymenolobium sp. & French Guiana & 600 \\
\hline 16627 & Pseudopiptadenia suaveolens Brenan & French Guiana & 875 \\
\hline 16641 & Parkia nitida Miq. & French Guiana & 232 \\
\hline 16664 & Bagassa guianensis Aubl. & French Guiana & 1076 \\
\hline 16725 & Discoglypremna caloneura Prain & Gabon & 406 \\
\hline 16790 & Faucherea parvifolia H.Lec. & Madagascar & 853 \\
\hline 16796 & Brachylaena ramiflora Humbert & Madagascar & 866 \\
\hline 17431 & Simarouba amara Aubl. & French Guiana & 455 \\
\hline 18077 & Gossweilerodendron balsamiferum Harms & Gabon & 460 \\
\hline 18127 & Manilkara mabokeensis Aubrev. & Central African R. & 944 \\
\hline 18283 & Shorea-rubro squamata Dyer & Philippine & 569 \\
\hline 18284 & Autranella congolensis A.Chev. & Central African R. & 956 \\
\hline 18412 & Entandrophragma angolense C.DC. & Congo & 473 \\
\hline 18752 & Distemonanthus benthamianus Baill. & Cameroon & 779 \\
\hline 19041 & Terminalia superba Engl. \& Diels & Cameroon & 583 \\
\hline 20030 & Nesogordonia papaverifera R.Cap. & Côte d'Ivoire & 768 \\
\hline 20049 & Albizia ferruginea Benth. & Côte d'Ivoire & 646 \\
\hline 20982 & Gymnostemon zaizou Aubrev. \& Pellegr. & Côte d'Ivoire & 380 \\
\hline 21057 & Anthonotha fragrans Exell \& Hillcoat & Côte d'Ivoire & 777 \\
\hline 24440 & Piptadeniastrum africanum Brenan & Côte d'Ivoire & 975 \\
\hline 25971 & Guibourtia ehie J.Leon. & Côte d'Ivoire & 783 \\
\hline 26439 & Manilkara huberi Standl. & Brazil & 1096 \\
\hline 27319 & Pometia pinnata Forst. & Salomon Islands & 713 \\
\hline 27588 & Glycydendron amazonicum Ducke & French Guiana & 627 \\
\hline 28071 & Cunonia austrocaledonica Brong. \& Gris. & New Caledonia & 621 \\
\hline 28082 & Nothofagus aequilateralis Steen. & New Caledonia & 1100 \\
\hline 28086 & Schefflera gabriellae Baill. & New Caledonia & 570 \\
\hline 28089 & Gymnostoma nodiflorum Johnst. & New Caledonia & 1189 \\
\hline 28099 & Dysoxylum sp. & New Caledonia & 977 \\
\hline 28100 & Calophyllum caledonicum Vieill. & New Caledonia & 789 \\
\hline 28102 & Gyrocarpus americanus Jacq. & New Caledonia & 206 \\
\hline 28103 & Pyriluma sphaerocarpum Aubrev. & New Caledonia & 793 \\
\hline 28163 & Cedrela odorata $\mathrm{L}$. & Guadeloupe & 512 \\
\hline 29468 & Moronobea coccinea Aubl. & French Guiana & 953 \\
\hline 29503 & Goupia glabra Aubl. & Brazil & 885 \\
\hline 29509 & Manilkara huberi Standl. & Brazil & 1187 \\
\hline 30231 & Micropholis venulosa Pierre & French Guiana & 665 \\
\hline 30258 & Cedrelinga catenaeformis Ducke & Brazil & 490 \\
\hline 30679 & Vouacapoua americana Aubl. & French Guiana & 882 \\
\hline
\end{tabular}


Table II. Xylophone maker's acoustic classification (best quality: 16211, worst quality: 16790).

\begin{tabular}{|c|c|c|c|c|c|c|c|c|c|}
\hline \multirow[b]{2}{*}{ Quality } & \multirow{2}{*}{$\begin{array}{c}\text { Good } \\
1\end{array}$} & \multicolumn{4}{|c|}{ Medium } & \multicolumn{4}{|c|}{ Poor } \\
\hline & & 2 & 3 & 4 & 5 & 6 & 7 & 8 & 9 \\
\hline \multirow[t]{2}{*}{1} & 16211 & 15366 & 16084 & 30231 & 15377 & 14814 & 5329 & 7299 & 29503 \\
\hline & Dalb. sp. & Humb. m.L. & Mono. h.P. & Micr. v.P. & Fauc. $t$. H.L. & Аисо. k.P. & Ongo. g.P. & Coul.e.B. & Goup. g. A. \\
\hline \multirow[t]{2}{*}{2} & 16624 & 30258 & 24440 & 28163 & 6779 & 20982 & 18127 & 15717 & 18284 \\
\hline & Hуте. sp. & Cedr.c.D. & Pipt. a.B. & Cedr. o.L. & Ocot. $r \mathrm{M}$. & Gymn. z.A.P. & Mani. m.A. & Ceib. p. G. & Autr.c.A.C. \\
\hline \multirow[t]{2}{*}{3} & 16136 & 27588 & 6704 & 18412 & 7021 & 13293 & 28102 & 18077 & 16725 \\
\hline & Comm. sp. & Glyc. a.D. & Humb. m.L. & Enta. a.C. & Khay. s.A.J. & Enta. c.S. & Gyro. a.J. & Goss. b.H. & Disc. c.P. \\
\hline \multirow[t]{2}{*}{4} & 28100 & 28099 & 6966 & 20049 & 30679 & 28071 & 28086 & 26439 & 16790 \\
\hline & Calo. c.V. & Dyso. sp. & Khay. g.C. & Albi.f.B. & Vоиа. а.А. & Сипо. а.B.G. & Sche. g. B. & Mani. h.S. & Fauc. p.H.L. \\
\hline \multirow[t]{2}{*}{5} & 14440 & 29468 & 16664 & 16641 & 27319 & 29509 & 20030 & 28082 & \\
\hline & Swie. m.K. & Moro. c.A. & Baga. g.A. & Park. n.M. & Pome. p.F. & Mani. h.S. & Neso. p.R.C. & Noth. a.S. & \\
\hline \multirow[t]{2}{*}{6} & 16627 & 14233 & 18283 & 19041 & & 4271 & 25971 & 28103 & \\
\hline & Pseu.s. B. & Afze.p.H. & Shor. s.D. & Term. s.E.D & & Scot. k.P. & Guib. e.J.L. & Pyri. s.A. & \\
\hline \multirow[t]{2}{*}{7} & 17431 & 11136 & 18752 & 16796 & & 21057 & 16001 & 28089 & \\
\hline & Sima. a. A. & Tarr. j.B1. & Dist. b.B. & Brac. $r . \mathrm{H}$. & & Anth. f.E.H. & Lete. d.H.L. & Gymn.n.J. & \\
\hline
\end{tabular}

In the second approach, the sound signal "descriptor" parameters were used in the temporal space. The parametric method of SteiglitzMcBride [20] was used to simultaneously determine the amplitude $\beta_{\mathrm{i}}$ and the temporal damping $\alpha_{\mathrm{i}}$ associated with the resonance frequency (4). In the equation (4), the summation was limited to the first three resonance frequencies because of the frequency contents of measured signals (excitation of specimens by a finite impulse which acts as a low pass filter in addition with the damping properties of wood material).

$$
s(t) \approx \sum_{i=1}^{3} \beta_{i} \exp \left(-\alpha_{i} t\right) \sin \left(2 \pi f_{i} t+\varphi_{i}\right)
$$

where $\mathrm{s}$ is the radiated signal as a function of time $t, f_{i}$ is the resonance frequency of the order $i$ and $\varphi_{i}$ is the phase shift. Amongst the temporal descriptors, dissipation in wood material under longitudinal or transverse vibration conditions is usually characterized by a logarithmic decrement calculation $[2,16,19]$. This value, relative to a free-free vibration frequency of the material, can be used through a generalization of the vibrational response of a dissipative system at one degree of freedom (5) and via complex dissipative systems [17].

$$
s(t) \approx \sum_{i=1}^{3} \beta_{i} \exp \left(-\lambda_{i} 2 \pi f_{i} t\right) \sin \left(\left(2 \pi f_{i} \sqrt{1-\lambda_{i}^{2}}\right) t+\varphi_{i}\right)
$$

when the damping rate $\lambda_{i}$ is much lower than 1 , the logarithmic decrement $\delta_{\log (i)}$ is proportional to the damping rate [2]. The damping rate and logarithmic decrement are thus linked by the following relation (6):

$$
\delta_{\log (i)} \approx 2 \pi \lambda_{i} .
$$

Logarithmic decrement studies have been carried out notably by Kollmann [8], Bordonné [2] and Holz [7] among others. A lack of relationship between the density and the logarithmic decrement $\delta_{\log (i)}$ was experimentally noted by Kollmann [8] in oak and spruce, and by Bordonné [2] in tropical species. However, Bordonné [2] observed a regular increase in the logarithmic decrement with the associated frequency in kaori, which is a softwood. This trend was also noted by Holz [7] in spruce.

Temporal descriptors, along with associated vibrational frequencies, of a dynamic dissipation phenomenon in a material are all equivalent, but it is important to specify the equations that link these different parameters. Equation (6) establishes the first linkage. For additive synthesis of a real signal, the signal must be composed of a sum of exponentially damped sinusoids (4). The combined use of additive synthesis models and waveguide synthesis can highlight relationships between different signal damping, damping rate $\lambda_{i}$, temporal damping $\alpha_{i}$, and internal friction $\tan \delta_{i}$ quantitative values associated with the complex modulus concept [18] with respect to transverse vibrations [3]:

$$
\begin{gathered}
\alpha_{i}=2 \pi \lambda_{i} f_{i} \\
\alpha_{i}=\frac{\pi}{2} f_{i} \tan \delta_{i} .
\end{gathered}
$$

In the third approach, the signal was used to determine the mechanical parameters of the material $[5,9]$. The longitudinal modulus of elasticity and the transverse shear modulus can be calculated when the geometry and mass of the test samples are known [4].

\section{RESULTS AND DISCUSSION}

\subsection{Acoustic and multisensory classifications of the xylophone maker}

The acoustic and multisensory classification results are given in Tables II and III. The classifications are linear-graded from best to worst - with the results separated in three separate groups, i.e. good, medium and poor. The xylophone maker detected eight odd samples due to defects or cutting problems (Tab. III). These odd samples were excluded from the analyses.

During the multisensory classification, the xylophone maker separated the low and high density woods (Tab. III). The light woods had some defects that would hamper their professional use, i.e. fragility, instability and lack of acoustic power. However, these two categories were not differentiated in the acoustic classification (Tab. II). The density was not reflected in the acoustic information. The two classifications were still coherent since the very good and very poor acoustic quality samples were properly positioned at the extremes in the two tables (Tabs. II and III). In the qualitative classification, the acoustic information thus took precedence over the esthetic and textural features. 
Table III. Xylophone maker's multisensory classification (best quality: 16211, worst quality: 7299). Odd samples were not taken into account in further analyses.

\begin{tabular}{|c|c|c|c|c|c|c|}
\hline \multirow{3}{*}{ Quality } & \multicolumn{6}{|c|}{ Medium or high density (from 600 to $1277 \mathrm{~kg} / \mathrm{m}^{3}$ ) } \\
\hline & \multicolumn{2}{|c|}{ Good } & \multicolumn{2}{|c|}{ Medium } & \multicolumn{2}{|c|}{ Poor } \\
\hline & 1 & 2 & 3 & 4 & 5 & 6 \\
\hline 1 & $\begin{array}{c}16211 \\
\text { Dalb. sp. }\end{array}$ & $\begin{array}{c}15366 \\
\text { Humb. m.L. }\end{array}$ & $\begin{array}{c}18752 \\
\text { Dist. b.B. }\end{array}$ & $\begin{array}{c}25971 \\
\text { Guib. e.J.L. }\end{array}$ & $\begin{array}{c}7021 \\
\text { Khay. s.A.J. }\end{array}$ & $\begin{array}{c}29509 \\
\text { Mani. h.S. }\end{array}$ \\
\hline 2 & $\begin{array}{c}16624 \\
\text { Hyme. sp. }\end{array}$ & $\begin{array}{c}24440 \\
\text { Pipt. a.B. }\end{array}$ & $\begin{array}{c}27588 \\
\text { Glyc. a.D. }\end{array}$ & $\begin{array}{c}6966 \\
\text { Khay. g.C. }\end{array}$ & $\begin{array}{c}28071 \\
\text { Cuno. a.B.G. }\end{array}$ & $\begin{array}{c}30679 \\
\text { Voua. a. A. }\end{array}$ \\
\hline 3 & $\begin{array}{c}28100 \\
\text { Calo. c.V. }\end{array}$ & & $\begin{array}{c}11136 \\
\text { Tarr. j.B1. }\end{array}$ & $\begin{array}{c}6704 \\
\text { Humb. m.L. }\end{array}$ & $\begin{array}{c}6779 \\
\text { Ocot. } r \mathrm{M} .\end{array}$ & $\begin{array}{c}5329 \\
\text { Ongo. g.P. }\end{array}$ \\
\hline 4 & $\begin{array}{c}14233 \\
\text { Afze.p. } \mathrm{H} .\end{array}$ & & $\begin{array}{c}16796 \\
\text { Brac. r.H. }\end{array}$ & $\begin{array}{c}18283 \\
\text { Shor. s.D. }\end{array}$ & $\begin{array}{c}15377 \\
\text { Fauc. t.H.L. }\end{array}$ & $\begin{array}{c}7299 \\
\text { Coul. e.B. }\end{array}$ \\
\hline 5 & $\begin{array}{c}28099 \\
\text { Dyso. sp. }\end{array}$ & & $\begin{array}{c}16664 \\
\text { Baga. g.A. }\end{array}$ & $\begin{array}{c}20049 \\
\text { Albi.f.B. }\end{array}$ & $\begin{array}{c}18127 \\
\text { Mani. m.A. }\end{array}$ & \\
\hline 6 & $\begin{array}{c}16627 \\
\text { Pseu.s. B. }\end{array}$ & & $\begin{array}{c}4271 \\
\text { Scot. } k . P .\end{array}$ & $\begin{array}{c}20030 \\
\text { Neso. p.R.C }\end{array}$ & $\begin{array}{c}16001 \\
\text { Lete. } d . \mathrm{H} . \mathrm{L} .\end{array}$ & \\
\hline \multirow[t]{2}{*}{7} & $\begin{array}{c}29468 \\
\text { Moro. c.A. }\end{array}$ & & $\begin{array}{c}21057 \\
\text { Anth.f.E.H. }\end{array}$ & $\begin{array}{c}27319 \\
\text { Pome.p.F. }\end{array}$ & $\begin{array}{c}28103 \\
\text { Pyri.s.A. }\end{array}$ & \\
\hline & \multicolumn{4}{|c|}{ Low density (from 206 to $600 \mathrm{~kg} / \mathrm{m}^{3}$ ) } & \multirow{3}{*}{\multicolumn{2}{|c|}{ Odd samples }} \\
\hline \multirow[t]{2}{*}{ Quality } & \multicolumn{2}{|c|}{ Good } & \multicolumn{2}{|c|}{ Medium } & & \\
\hline & 1 & 2 & 3 & 4 & & \\
\hline 1 & $\begin{array}{c}16136 \\
\text { Comm. sp. }\end{array}$ & $\begin{array}{c}28163 \\
\text { Cedr. o.L. }\end{array}$ & $\begin{array}{c}18077 \\
\text { Goss. b.H. }\end{array}$ & & $\begin{array}{c}14814 \\
\text { Auco. k.P. }\end{array}$ & $\begin{array}{c}28089 \\
\text { Gymn. n.J. }\end{array}$ \\
\hline 2 & $\begin{array}{c}30231 \\
\text { Micr. v.P. }\end{array}$ & $\begin{array}{c}16084 \\
\text { Mono. h.P. }\end{array}$ & $\begin{array}{c}28102 \\
\text { Gyro. a.J. }\end{array}$ & & $\begin{array}{c}28082 \\
\text { Noth. a.S. }\end{array}$ & \\
\hline 3 & $\begin{array}{c}14440 \\
\text { Swie. m.K. }\end{array}$ & $\begin{array}{c}28086 \\
\text { Sche. g. B. }\end{array}$ & $\begin{array}{c}20982 \\
\text { Gymn. z.A.P. }\end{array}$ & & $\begin{array}{c}13293 \\
\text { Enta. c.S. }\end{array}$ & \\
\hline 4 & $\begin{array}{c}18412 \\
\text { Enta. a.C. }\end{array}$ & & $\begin{array}{c}15717 \\
\text { Ceib.p.G. }\end{array}$ & & $\begin{array}{c}26439 \\
\text { Mani. h.S. }\end{array}$ & \\
\hline 5 & $\begin{array}{c}30258 \\
\text { Cedr. c.D. }\end{array}$ & & $\begin{array}{c}16725 \\
\text { Disc. c.P. }\end{array}$ & & $\begin{array}{c}16790 \\
\text { Fauc. p.H.L. }\end{array}$ & \\
\hline 6 & $\begin{array}{c}19041 \\
\text { Term. s.E.D. }\end{array}$ & & $\begin{array}{c}16641 \\
\text { Park. n.M. }\end{array}$ & & $\begin{array}{c}18284 \\
\text { Autr. c.A.C. }\end{array}$ & \\
\hline 7 & $\begin{array}{c}17431 \\
\text { Sima. a. A. }\end{array}$ & & & & $\begin{array}{c}29503 \\
\text { Goup. g. A. }\end{array}$ & \\
\hline
\end{tabular}

\subsection{Comparison of the acoustic classification and the signal processing analysis results}

The number of samples analysed was reduced to 50 after the 8 odd samples were eliminated from the initial batch. The 14 parameters derived from the sound signal analysis are presented in Table IV. The aim here was to identify parameters that would best account for the xylophone maker's acoustic classification.

The bivariate correlation matrix (Fig. 2) calculated on the basis of the 14 characteristic parameters revealed close colinearity between these parameters. A principal component analysis was thus conducted. This analysis generated a new set of parameters derived from the original set in which the new parameters (principal components) were not correlated and closely represented the variability of the original set. Table V shows that five principal components accounted for $94 \%$ of all information contained in the 14 original parameters.

A hierarchical cluster analysis was performed on the basis of the principal components, such that: (a) the measurement of similarities between studied individuals is a distance measurement, (b) the distance measurement is the Euclidian distance calculated in the orthogonal space formed by the five standard principal components, and (c) the agglomeration method uses the mean distance between groups.

The resulting tree diagram highlighted three groups, called G1, G2 and G3. The composition of these groups was compared to that of the three groups derived from the xylophone maker's acoustic classification on the basis of the contingency table (Tab. VI). This table indicates differences between the acoustic and hierarchical classifications. Two different hypotheses 
Table IV. Characteristic parameters computed from dynamic test results.

\begin{tabular}{ll}
\hline No. & \multicolumn{1}{c}{ Characteristic parameters } \\
\hline 1 & Density \\
2 & Longitudinal modulus of elasticity $\left(\mathrm{E}_{\mathrm{L}}\right)$ \\
3 & Shear modulus $\left(\mathrm{G}_{\mathrm{TL}}\right)$ \\
4 & Ratio: modulus of elasticity/density \\
5 & Ratio: shear modulus/density \\
6 & Rank 1 vibration frequency (fundamental) \\
7 & Rank 2 vibration frequency (1st harmonic) \\
8 & Harmonicity factor $(H F)$ \\
9 & Spectral center of gravity $(S C G)$ \\
10 & Spectral range $(S R)$ \\
11 & Fundamental amplitude $\left(\beta_{1}\right)$ \\
12 & 1st harmonic amplitude $\left(\beta_{2}\right)$ \\
13 & Fundamental damping coefficient $\left(\alpha_{1}\right)$ \\
14 & 1st harmonic damping coefficient $\left(\alpha_{2}\right)$ \\
\hline
\end{tabular}

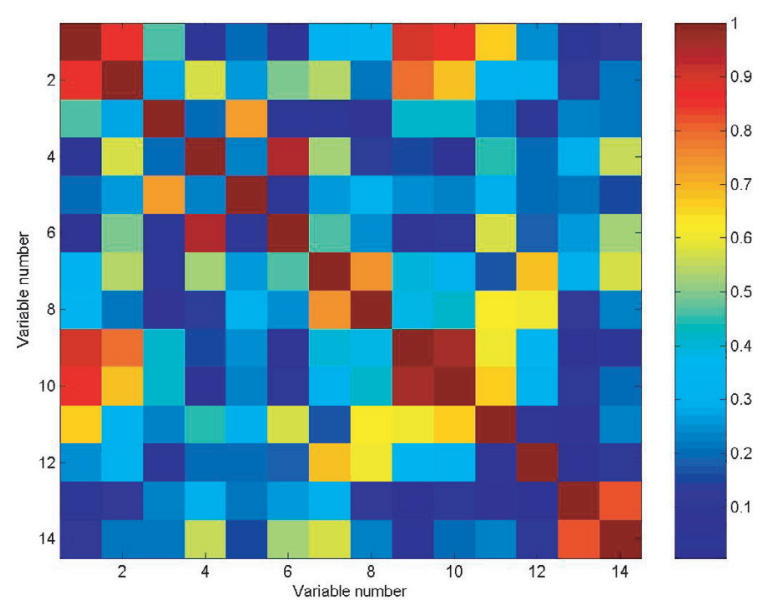

Figure 2. Absolute bivariate correlation coefficients for characteristic parameters ${ }^{1}$.

might explain this lack of fit, i.e. either (1) the xylophone maker based his classification on information other than that contained in the parameters used, or (2) he only used part of the information of parameters derived from the sound signal analysis.

A partial least-squares regression model was used to determine whether either of these hypotheses applied. By this regression method, a multiple linear regression is performed on a new set of variables (latent variables) assembled by taking the variability in the original set as well as the variability in the target set (here the xylophone maker's acoustic classification) into account [22]. A unitary distance between two samples in the acoustic classification was arbitrarily attributed in order to make the acoustic classification variable quantitative.

The partial least squares regression obtained was highly significant $\left(R^{2}=0.74\right.$, Tab. VII). The two latent variables that best accounted for the xylophone maker's classification pooled an
Table V. Total variance explained by principal components.

\begin{tabular}{lcc}
\hline No. PC & \% of variance & \% Cumulative \\
\hline 1 & 35 & 35 \\
2 & 26 & 61 \\
3 & 15 & 76 \\
4 & 10 & 86 \\
5 & 8 & 94 \\
\hline
\end{tabular}

Table VI. Comparison of acoustic classification and hierarchical clustering performed on principal components (contingency table).

\begin{tabular}{lccc}
\hline Size of group & G1 & G2 & G3 \\
\hline Good & 3 & 4 & 0 \\
Medium & 7 & 16 & 3 \\
Poor & 4 & 7 & 6 \\
\hline
\end{tabular}

Table VII. Total variance explained by latent variables (NIPALS algorithm).

\begin{tabular}{|c|c|c|c|c|}
\hline \multirow{2}{*}{$\begin{array}{l}\text { Latent } \\
\text { variable }\end{array}$} & \multicolumn{2}{|c|}{$\begin{array}{c}\text { Characteristics } \\
\text { parameters }\end{array}$} & \multicolumn{2}{|c|}{$\begin{array}{c}\text { Acoustic } \\
\text { classification }\end{array}$} \\
\hline & $\begin{array}{c}\% \text { of } \\
\text { variance }\end{array}$ & $\begin{array}{c}\% \\
\text { cumulative }\end{array}$ & $\begin{array}{c}\% \text { of } \\
\text { variance }\end{array}$ & $\begin{array}{c}\% \\
\text { cumulative }\end{array}$ \\
\hline 1 & 20 & 20 & 58 & 58 \\
\hline 2 & 19 & 39 & 16 & 74 \\
\hline
\end{tabular}

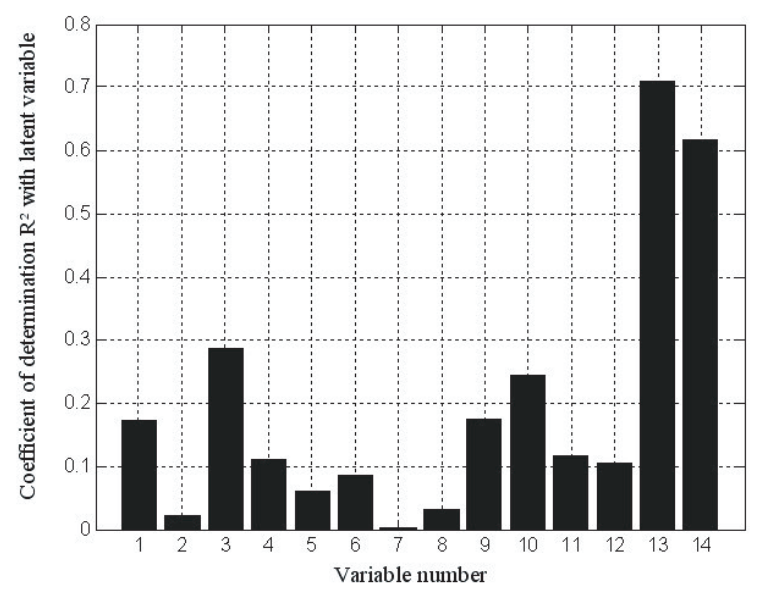

Figure 3. Bilateral regression coefficients for variables and latent variable 1.

equal share of the experimental information (around 20\% per variable). However, the first latent variable accounted for a major part (58\%, Tab. VII) of the variability noted in the xylophone maker's acoustic classification.

Figure 3 shows that the first latent variable pooled information contained in the temporal damping variables (Nos. 13 and 14, Tab. IV), which were closely correlated (Fig. 2). The second

\footnotetext{
${ }^{1}$ Figure available in colour at www.edpsciences.org/forest
} 


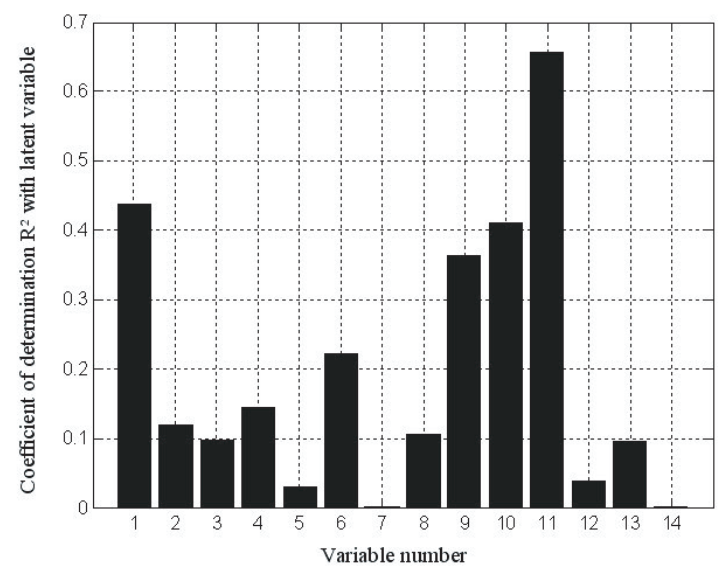

Figure 4. Bilateral regression coefficients for variables and latent variable 2 .

latent variable pooled information of variables No. 1, 9, 10 and 11 (Fig. 4). The fundamental frequency amplitude was the original variable best represented by this latent variable (No. 11, Tab. IV). The other original variables (Nos. 1, 9 and 10) were represented by this latent variable because of their close correlation with variable No. 11 (Fig. 4). The xylophone maker's choices were thus mainly influenced by temporal damping of the fundamental frequency, and to a lesser extent by the amplitude of this frequency.

Note that the classified samples were not musically tuned. Between-specimen differences in pitch hampered clear comparisons between species. This could account for the absence of frequency descriptor in the explanation of the xylophone maker's choices.

\subsection{Acoustic classification and wood anatomy}

The study of the relationship between the qualitative classification and anatomical structure of the wood specimens was focused on species ranked at both extremes of the classification. The discussion is thus mainly hinged on the seven species classified as "good" and the seven species classified as "poor" in both the acoustic and multisensory classifications (Tab. VIII).

\subsubsection{Vessel elements}

All tested specimens were tropical woods, so there was very little variation in the vessel diameters within each annual growth ring, except for the Dalbergia from Madagascar which showed clear semi-ring-porous areas. The mean tangential diameter ranged from 140 to $280 \mu \mathrm{m}$ in all of the good acoustic woods and from 60 to $160 \mu \mathrm{m}$ in the poor acoustic woods. The vessel frequency $/ \mathrm{mm}^{2}$ ranged from 2 to 8 (up to 18 in Commiphora) in the "good" specimens, and from 7 (4 in Letestua) to 20 (50 in Cunonia) in the "poor" specimens. The vessels were solitary and in radial multiples of 2 to 4 in most of the woods, but they were exclusively solitary in Cunonia and Ongokea (poor acoustics) and in Calophyllum (good acoustics), whereas they were commonly in radial multiples of 4 and more in Letestua
Table VIII. Species with the best and worst acoustic qualities which were classified identically in the acoustic and multisensory tests.

\begin{tabular}{ll}
\hline Good acoustic quality & Poor acoustic quality \\
\hline Dalbergia sp. & Coula edulis Baill. \\
Hymenolobium $\mathrm{sp}$. & Ongokea gore Pierre \\
Commiphora sp. & Manilkara huberi Standl. \\
Calophyllum caledonicum Vieill. & Pyriluma sphaerocarpum Aubrev. \\
Swietenia macrophylla King & Letestua durissima H.Lec. \\
Pseudopiptadenia suaveolens & Manilkara mabokeensis Aubrev. \\
Brenan & \\
Simarouba amara Aubl. & Cunonia austrocaledonica Brong. \\
& \& Gris. \\
\hline
\end{tabular}

and Pyriluma (poor acoustics) and Hymenolobium (good acoustics). They were generally diffuse but with a tendency to be arranged radially in Letestua, Manilkara and Pyriluma (typical feature of woods belonging to the Sapotaceae family).

\subsubsection{Axial parenchyma}

The axial parenchyma was found to be mainly paratracheal in the good acoustic woods, ranging from scanty paratracheal (Calophyllum, Commiphora and Swietenia) or lozenge-aliform - (Dalbergia, Pseudopiptadenia and Simarouba) to highly abundant and very confluent, forming wide bands linking vessels (Hymenolobium). Only Calophyllum and Swietenia had an apotracheal parenchyma, i.e. the first in the form of a few short to long bands, and the latter in marginal bands. All wood specimens with poor acoustics had an apotracheal parenchyma, i.e. abundant diffuse-in-aggregates parenchyma (Coula, Cunonia, Ongokea and Pyriluma) or with many tangential narrow bands (Letestua and Manilkara).

\subsubsection{Rays}

In the good acoustic woods the rays frequency ranged from 4 to $9 / \mathrm{mm}$. The rays were $1-3$ - to 4 -seriate (15-55 $\mu \mathrm{m}$ wide) and 180-500 $\mu \mathrm{m}$ high. Their structure was homogeneous or subhomogeneous, i.e. composed only of procumbent cells or procumbent cells with one row of square marginal cells. In the poor acoustic woods the rays frequency ranged from 9 to $16 / \mathrm{mm}$. The rays were 2-4- to 5-seriate (20-50 $\mu \mathrm{m}$ wide) and 400-1000 $\mu \mathrm{m}$ high. Their structure was heterogeneous, i.e. procumbent cells in the body with several rows of square and/or upright marginal cells.

\subsubsection{Fibres}

The wood fibres in specimens with good acoustics were relatively short, i.e. from $900 \mu \mathrm{m}$ (Dalbergia) to $1300 \mu \mathrm{m}$ (Swietenia) long, and up to $2000 \mu \mathrm{m}$ in Hymenolobium, wide from $19 \mu \mathrm{m}$ (Pseudopiptadenia) to $36 \mu \mathrm{m}$ (Commiphora), with a lumen diameter ranging from $9 \mu \mathrm{m}$ (Pseudopiptadenia) to $28 \mu \mathrm{m}$ (Commiphora). Fibres in the poor acoustic woods were $1300 \mu \mathrm{m}$ (Ongokea) to $2000 \mu \mathrm{m}$ (Coula) long, and $20 \mu \mathrm{m}$ (Manilkara) to $34 \mu \mathrm{m}$ (Ongokea) wide, with a lumen diameter 
of less than $10 \mu \mathrm{m}$. All woods with good acoustics had libriform fibres (simple pits), whereas those with poor acoustics had either libriform fibres (Letestua, Manilkara and Pyriluma) or fibre-tracheids (bordered pits), e.g. Coula, Cunonia and Ongokea.

\subsubsection{Storied structure}

All poor acoustic woods as well as three with good acoustics (Calophyllum, Commiphora and Pseudopiptadenia) did not show a storied structure. However, all the axial elements and the rays have a clearly defined horizontal storied pattern in Dalbergia and Hymenolobium, with a relatively storied pattern in Simarouba and Swietenia.

\subsubsection{Relationship between the acoustic classification and the wood anatomy}

The acoustic quality of the woods could not be explained by any vessel characteristics. The present findings do not comply with the theory that the narrow diameter and high frequency of vessels in wood is detrimental to acoustic quality since Ceiba and Discoglypremna, which only have a few $\left(1-2 / \mathrm{mm}^{2}\right)$ large vessels (around $200 \mu \mathrm{m}$ diameter), had very poor acoustics.

However, the parenchyma tissue, depending on their distribution patterns and abundance, seemed to have an impact on the acoustic quality. Woods with the best acoustics had axial parenchyma, which was mainly paratracheal and not very abundant (but this latter condition did not seem critical), with only a few short rays, and definitely with a homogeneous structure.

Characterization of the organization of wood components could be enhanced by approaching it from a different perspective, i.e. assuming that woods with the best acoustic qualities have wood structure not regularly disrupted by parenchyma. There are always tangential disruptions due to the presence of rays (a few wood rayless species exist, but these are rare scientific curiosities). These disruptions are minimized when only a few small rays are present. Radial disruptions in the wood structure consistency are primarily due to the presence of vessels (this applies to all woods tested in the present study, but woods of gymnosperm species and of a few rare small dicot families do not have vessels). Hence, woods with few vessels should theoretically have better acoustics than very porous woods. The presence of paratracheal parenchyma does not increase the number of disruptions in the fibrous tissues but it slightly increases disruptions induced by the vessels. However, apotracheal parenchyma, diffuse-in-aggregates or in tangential bands, regularly and frequently disrupts the radial cohesion between fibres. For instance, in the woods with good acoustics, the fibrous tissue was radially disrupted about twice/cm by marginal parenchyma bands in Swietenia, 15 times by bands in Hymenolobium, while in the woods with poor acoustics the tissues were disrupted $35-50$ times/cm by parenchyma bands in Manilkara and up to 120 times/cm by diffuse-in-aggregates parenchyma in Pyriluma.

The fibre morphology did not seem to have a major impact on the acoustic quality of the woods as long as the lumen diameter was $10 \mu \mathrm{m}$ or more, i.e. the fibre flexibility coefficient (lumen diameter/fibre width $\times 100$ ) had to be above 40 or so.
A storied wood structure does not always ensure good acoustics but it likely does enhance the sound quality.

We did not experimentally assess the impact of some anatomic features of the wood specimens on acoustic quality. However, a few structural characteristics of the specimens that were classified (in terms of acoustic quality) as slightly less good than the top seven woods and not quite as bad as the poorest woods could be briefly considered.

Of the specimens ranked just under the seven best woods in the acoustic classification, Humbertia, Cedrelinga and Afzelia had a scanty paratracheal or lozenge-aliform parenchyma (Afzelia) as well as a few diffuse parenchyma in the top two species or narrow marginal bands (Afzelia). They had many rays (5-8/mm), that were short (less than $300 \mu \mathrm{m}$ high) with a homogeneous structure. The vessel frequency was $1-5 / \mathrm{mm}^{2}$. The fibre lumen diameter was very narrow in Humbertia and Afzelia, but very wide in Cedrelinga. Finally, none of these three woods had a storied structure.

The three species that were ranked just above the seven poorest woods in the acoustic classification were Discoglypremna, Nesogordonia and Ceiba. All three had a diffuse-in-aggregate parenchyma. Their rays were either relatively low $(250-650 \mu \mathrm{m}$ high) and numerous (10-15/mm) in the first two species, or few in number $(5 / \mathrm{mm})$ but very high (more than $1200 \mu \mathrm{m})$ in Ceiba, with a heterogeneous (Discoglypremna and Ceiba) or subhomogeneous (Nesogordonia) structure. The vessel frequency was $1-3 / \mathrm{mm}^{2}$ in Discoglypremna and Ceiba, and around $20 / \mathrm{mm}^{2}$ in Nesogordonia. The fibre lumen diameter was relatively narrow in this species, but wide to very wide in the other two. The wood structure was regularly storied including the rays in Nesogordonia, but with most of the rays nonstoried in Ceiba.

\section{CONCLUSION}

When analyzing materials it is essential to determine the relationships between the manufacturing process (in our case the wood development), the microstructure and properties, while also correlating the properties with performance. This is useful for designing methods to help users make optimal choices on materials and implementation conditions, and to determine cost-effective ways of achieving the best performance, increasing the reliability of the materials and controlling assembly processes. The properties of cellular solids depend on two sets of parameters; those which describe the geometric internal structure and those which describe the intrinsic properties of the material of which the cell walls are made. When the material is wood, each species could be considered as a "wood factory" that produces a unique wood, always having the same basic composition: a cellular composite consisting of cellulose, lignin and hemicelluloses containing various quantities of extractives. The most marked variations between species are noted in the cellular organization pattern, i.e. the distinctive "fingerprint" of each species. It is thus of interest to assess the relationship between these patterns and the acoustic or vibratory properties of the wood and to compare them with the acoustic performances responsible for the acoustic quality.

The percussive acoustic quality of a wood, as determined empirically by the xylophone maker, can first be related to the 
two sound signal parameters, i.e. temporal damping of the fundamental frequency and to a lesser extent the amplitude of this frequency. The wood density doesn't impact this acoustic quality, but the light woods have some technological drawbacks.

Our analysis of the organization of wood components in the tested species relative to the acoustic quality classification highlighted the importance of the regularity and homogeneity of the anatomical structures.

A draft anatomical portrait of a good acoustic wood could be drawn up on the basis of our analysis of wood structures in the seven acoustically best and seven poorest woods. This portrait should include a compulsory characteristic, an important characteristic and two or three others of lesser importance.

The axial parenchyma is the key trait. It should be paratracheal, and not very abundant if possible. If abundant (thus highly confluent), the bands should not be numerous. Apotracheal parenchyma can be present, but only in the form of well spaced bands (e.g. narrow marginal bands).

The rays (horizontal parenchyma) are another important feature. They should be short, structurally homogeneous but not very numerous.

The other characteristics are not essential, but they could enhance the acoustic quality. These include:

- Small numbers of vessels (thus large);

- A storied structure;

- Fibres with a wide lumen (or a high flexibility coefficient).

The samples tested in this study were not musically confirmed, so the analysis was biased since no frequency descriptor could be identified. This parameter should be taken into consideration in future studies in order to come up with a more exhaustive list of parameter descriptors of acoustic quality for wood specimens and to identify other subtle features associated with acoustic quality.

Acknowledgements: The authors are extremely grateful to Robert Hébrard, musical instrument designer and xylophone maker, who gave useful advices and performed the acoustic and the multisensory classification of the wood specimens.

\section{REFERENCES}

[1] Bismarck G., Sharpness as an attribute of the timbre of steady sounds, Acustica J. 30 (1974) 146-158.

[2] Bordonné P.A., Module Dynamique et Frottement Intérieur dans le Bois - Mesures sur Poutres Flottantes en Vibrations Naturelles, $\mathrm{Ph} . \mathrm{D}$. thesis, Institut National Polytechnique de Lorraine, 1989.
[3] Brancheriau L., Expertise mécanique des sciages par analyses des vibrations dans le domaine acoustique, Ph.D. thesis, École supérieure de mécanique de Marseille, 2002.

[4] Brancheriau L., Baillères H., Natural vibration analysis of clear wooden beams: a theoretical review, Wood Sci. Technol. J. 36 (2002) 347-365.

[5] Bucur V., Acoustics of wood, CRC Press, 1995, pp. 135-143.

[6] Grey J.M., Multidimensional perceptual scaling of musical timbres, J. Acous. Soc. Am. 61 (1977) 1270-1277.

[7] Holz D., Tropical hardwoods used in musical instruments - can we substitute them by temperate zone species? Holzforschung J. 50 (1996) 121-129.

[8] Kollmann F.F.P., Côté W.A.J., Principles of wood science and technology, Springer-Verlag, Berlin, 1968, pp. 274-281.

[9] Martinis R., Valentina Socco L., Sambuelli L., Nicolotti G., Schmitt O., Bucur V., Tomographie ultrasonore pour les arbres sur pied, Ann. For. Sci. 61 (2004) 157-162.

[10] Matsunaga M., Sugiyama M., Minato K., Norimoto M., Physical and mechanical properties required for violin bow materials, Holzforschung J. 50 (1996) 511-517.

[11] Matsunaga M., Minato K., Physical and mechanical properties required for violin bow materials. II: Comparison of the processing properties and durability between pernambuco and substitutable wood species, J. Wood Sci. 44 (1998) 142-146.

[12] Matsunaga M., Minato K., Nakatsubo F., Vibrational property changes of spruce wood by impregnating with water-soluble extractives of pernambuco (Guilandina echinata Spreng.), J. Wood Sci. 45 (1999) 470-474.

[13] McAdams S., Winsberg S., Donnadieu S., De Soete G., Krimphoff J., Perceptual scaling of synthesized musical timbres: common dimensions, specificities and latent subject classes, Psychol. Res. J. 58 (1995) 177-192.

[14] Obataya E., Umezawa T., Nakatsubo F., Norimoto M., The effects of water soluble extractives on the acoustic properties of reed (Arundo donax L.), Holzforschung J. 53 (1999) 63-67.

[15] Ono T., Norimoto M., Study on Young's modulus and internal friction of wood in relation to the evaluation of wood for musical instruments, Jap. J. Appl. Phys. 22 (1983) 611-614.

[16] Ouis D., Vibrational and acoustical experiments on logs of spruce, Wood Sci. Technol. J. 33 (1999) 151-184.

[17] Ouis D., Detection of decay in logs through measuring the dampening of bending vibrations by means of a room acoustical technique, Wood Sci. Technol. J. 34 (2000) 221-236.

[18] Ouis D., On the frequency dependence of the modulus of elasticity of wood, Wood Sci. Technol. J. 36 (2002) 335-346.

[19] Pellerin R.F., Vibrational approach to nondestructive testing of structural lumber, For. Prod. J. 15 (1965) 93-101.

[20] Steiglitz K., McBride L.E., A Technique for the Identification of Linear Systems, IEEE Trans. Automat. Contr. 10 (1965) 461-464.

[21] Sugiyama M., Matsunaga M., Minato K., Norimoto M., Physical and mechanical properties of pernambuco (Guilandina echinata Spreng.) used for violin bows, Mokuzai Gakkaishi 40 (1994) 905910.

[22] Tenenhaus M., La Régression PLS : Théorie et Pratique, Technip, Paris, 1998. 